\title{
PCR detection of Salmonella spp. in Fresh Vegetables and Feed
}

\author{
Qadoumi Samar ${ }^{1}$, Dura Susan A.M. ${ }^{2}$, Darwish Maysa ${ }^{1}$, Ahmad M. Nahed ${ }^{2}$ \& El-Banna, Nasser. \\ ${ }^{1}$ Microbiology Department, National Agricultural Research Center, Baqa', Jordan \\ ${ }^{2}$ Biotechnology Department, National Center for Agricultural Research and Extension, Baqa', Jordan \\ ${ }^{3}$ Medical Laboratory Sciences, College of Sciences, Al-Balqa Applied University, Al-salt, Jordan \\ Correspondence: Qadoumi Samar, Microbiology Department, National Agricultural Research Center, Baqa', \\ Jordan. E-mail: qaddoumi_99@yahoo.com
}

\author{
Received: April 7, 2019 \\ Accepted: May 5, 2019 \\ Online Published: June 30, 2019 \\ doi:10.5539/ijb.v11n3p49 \\ URL: https://doi.org/10.5539/ijb.v11n3p49
}

\begin{abstract}
Salmonella have been some of the most prevalent reported etiological agents in fresh-produce-associated outbreaks of both human and animal infections. The current study aims to develop a suitable rapid and simple PCR-based protocol for routine analysis of Salmonella spp. in vegetables and forages. Fifty-two (32 vegetable and 20 forage) samples collected from different farms in Zarqa, Jordan, where recycled wastewater from Khirbet Al-Samra Wastewater Treatment Plant serves as the source of irrigation water were examined by standard microbiological techniques (SMT). The PCR assay for the detection of Salmonella species in the collected field samples revealed the same positive samples directly from the vegetables and forages which gave positive results by SMT. Thus PCR technique is rapid, time saving and applicable to detect Salmonella spp. directly from vegetable and forage samples. The combination of a routine PCR test in conjunction with SMT could be effective in providing a more accurate profile of the prevalence of Salmonella in fresh vegetable and forage related samples.
\end{abstract}

Keywords: Forage, nviA, Polymerase chain reaction, Salmonella spp., Vegetable

\section{Introduction}

Salmonellae have been some of the most ever-present reported etiological agents in fresh-produce-associated outbreaks of both human and animal infections in recent years. Different species of the bacterial genus Salmonella cause an astounding variety of diseases in both human and animal hosts. These range from asymptomatic persistence through gastric infections to potentially fatal systemic disease such as typhoid fever, with symptoms include sudden fever, headache, diarrhea, stomach cramps, nausea and sometimes vomiting. Symptoms can occur from 6 to 72 hours after becoming infected. Some species of this bacterium can infect a wide variety of hosts, while others are very specific to the host (Keusch, 2002). Salmonella has been linked with consumption of contaminated foods of animal origin, meat, eggs, poultry as well as dairy products. Constant variations in dietary habits and agronomic practices,

the increase in the consumption of vegetables that are consumed raw along with increased importation of fresh produce supposedly contribute to increase in the number of outbreaks associated with vegetables and animal feed of vegetable origin (Altekruse, Cohen, \& Swerdlow, 1997). Salmonella outbreaks have been linked to tomatoes (Centers for Disease Control and Prevention, 1993), seed sprouts (Mahon et al., 1997; O'Mahony et al., 1990), watermelons (Blostein, 1991; Centers for Disease Control and Prevention, 1979; Centers for Disease Control and Prevention, 1979), and animal feeds (Gooding \& Choudary, 1999; Rexach, Dilasser, \& Fach, 1994). Disposal of treated wastewater for agricultural irrigation simultaneously solves water shortage problems and reduces potential environmental contamination. In Jordan, it is not allowed to irrigate vegetables with treated wastewater. According to the Jordanian standards (893/2006), it could be used for irrigating forages, industrial crops, cut flowers and for Golf courses and we should apply some management practices according to the standards. However, subject to distribution of waterborne disease, associated with treated wastewater reuse, a risk assessment of pathogen hazards, subject to diverse wastewater qualities utilization, as well as different irrigation technologies, is require. Consumption of fresh vegetables and animal feed of vegetable origin was epidemiologically linked to many cases of Salmonella infection. Contamination of fresh produce with Salmonella may occur at any point along the farm-to-table continuum, and Salmonella probably occur 
intermittently at low levels together with the diverse natural flora. The established culture-based methods used to detect Salmonella in vegetable and animal feed of vegetable origin are laborious, time-consuming, and often not specific enough. The standard methods used today for analyzing Salmonella involve pre-enrichment in buffered peptone water (BPW), selective enrichment, plating on selective agar, and subsequent identification by biochemical tests (Bennettet al., 1998). The whole procedure takes at least mostly seven days to complete. Thus, rapid and sensitive methods for detecting Salmonella are in great demand in order to assure produce safety. One of the most promising methods for detecting Salmonella is based on the PCR, which combines simplicity with specificity and sensitivity for detecting the pathogens in food and feed. Several PCR assays have been developed by targeting various Salmonella genes, such as inv-A (Rahnet al., 1992; Wang, Blais, \& Yamazaki, 1995), 16S rRNA (Iidaet al., 1993), agf-A (Doranet al., 1993), and via-B (Hashimotoet al., 1995), and virulence-associated plasmids (Mahon \& Lax, 1993; Rexach, Dilasser, \& Fach, 1994). These PCR assays are used mainly for detecting Salmonella in poultry, meat and milk samples (Bennettet al., 1998; Bennettet al., 1998; Chenet al., 1997; Kimura et al., 1999). Few of the assays have been used to detect the pathogens in fresh product. Therefore, the aim of this study was to develop a rapid and simple PCR-based protocol suitable for routine analysis of Salmonella spp. in vegetables and animal feed of vegetable origin.

\section{Materials and Methods}

\subsection{Samples collection}

In the summer of 2016, fifty-two (32 vegetable and 20 forage) samples were collected from different farms in Zarqa, Jordan, where the source of irrigation water was recycled wastewater from Khirbet Al-Samra Wastewater Treatment Plant. The entire samples (Alfaalfa and white corn as Forage type and Cauliflower, Tomato and Egg plant: as vegetables) were placed under refrigerated conditions and transported to the laboratory for prompt processing and bacteriological examination.

\subsection{SMT for Salmonella identification and detection}

SMTs for various Salmonella spp. detection were carried out in accordance with ISO 6579-1: 2017; Briefly, $25 \mathrm{~g}$ of vegetable and forage samples were subjected to homogenization in a stomacher for $1-2 \mathrm{~min}$ in $225 \mathrm{ml}$ of buffered peptone water (BPW) and thereafter, under aerobic conditions $\left(\mathrm{T} 37^{\circ} \mathrm{C}\right.$ for 20 to $24 \mathrm{~h}$ ) were incubated by selective enrichment of 0.1 in $10 \mathrm{ml}$ of Rappaport-Vassilliadis (RV) broth. At $42^{\circ} \mathrm{C}$ for 18 to $24 \mathrm{~h}$, the RV broth was incubated, subcultured onto Xylose Lysine Desoxycholate (XLD) agar, Hektoen Enteric agar and Salmonella Chromogenic Agar and then re-incubated at $37^{\circ} \mathrm{C}$ for 18 to $24 \mathrm{~h}$. All media were provided by Oxoid, (Basingstoke, UK). Hypothetical positive colonies (non-lactose fermentative with appropriate colony morphology) were biochemically, morphologically and serologically identified through slide agglutination test with polyvalent and monovalent somatic $(\mathrm{O})$, virulent $(\mathrm{Vi})$ as well as tube agglutination test for flageller $(\mathrm{H})$ antigens (Defco Laboratories, Detroit, Michigan, USA) in parallel with positive control ATCC 14028s. $1 \mathrm{ml}$ of $\mathrm{BPW}$ already incubated at $37^{\circ} \mathrm{C}$ was set aside for the PCR-Non Selective test (PCR-NS) and $1 \mathrm{ml}$ of the $37^{\circ} \mathrm{C}$ $\mathrm{RV}$ broth for the PCR-RV test.

\subsection{DNA extraction}

The cultures (Buffered Peptone Water and Rappaport-Vassilliadis) that stayed overnight were subjected to centrifugation at $5000 \mathrm{rpm}$ for $3 \mathrm{~min}$ and the supernatant were carefully decanted. The bacteria pellets were thrice washed using phosphate buffer saline $\mathrm{pH} 7.2$, which was resuspended in $400 \mu \mathrm{L}$ tris-EDTA buffer ( $\mathrm{pH}$ 8.0) and heated at $100^{\circ} \mathrm{C}$ in water bath for $30 \mathrm{~min}$. Thereafter, it was allowed to cool at room temperature and underwent centrifugation for $10 \mathrm{~min}$ at $14,000 \mathrm{rpm} .5 \mu \mathrm{L}$ aliquot of the supernatant was used as model DNA in the PCR.

\subsection{PCR primers, DNA amplification and detection}

A 26-bp forward primer (5'GTG AAA TTA TCG CCA CGT TCG GGC AA3') and a 22-bp reverse primer (5'TCA TCG CAC CGT CAA AGG AAC C3') (Moussaet al., 2010), targeting the inv-A Salmonella spp. gene, were utilized in PCR to achieve a 284-bp product. Amplification was conducted in $25 \mu$ l total volume containing $1.0 \mu \mathrm{M}$ each primer, $0.2 \mathrm{mM}$ each dNTP, $1.5 \mathrm{mM} \mathrm{MgCl}_{2}, 0.5 \mathrm{U}$ Taq DNA polymerase, 1 X PCR buffer and $5 \mu 1$ template. A negative control comprising similar reaction mixture but without the DNA template was added in all of the experiment. And a positive control (ATCC 14028s) is used.

An initial denaturation for $3 \mathrm{~min}$ at $95^{\circ} \mathrm{C}$ was accompanied by 35 denaturation cycles at $95^{\circ} \mathrm{C}$ for $10 \mathrm{~s}$, annealing at $64^{\circ} \mathrm{C}$ for $15 \mathrm{~s}$ and extension at $72^{\circ} \mathrm{C}$ for $5 \mathrm{~s}$. Finally, an additional extension was achieved for $10 \mathrm{~min}$ at $72^{\circ} \mathrm{C}$. An aliquot of $10-\mu \mathrm{l}$ of each of the PCR product underwent electrophoresis on a $1.0 \%$ agarose gel for $1.0 \mathrm{~h}$ at 100 
$\mathrm{V}$, stained in ethidium bromide $\left(0.5 \mu \mathrm{g} \mathrm{ml}^{-1}\right)$ for $10 \mathrm{~min}$, and then visualized and photographed under ultra-violet (UV) illumination.

\section{Results}

The standard microbiological techniques revealed positive isolation of only one Salmonella spp. (1.9\%) out of 52 examined vegetable and forage samples (Table 1).

The specificity of the oligonucleotid primers as well as typing of the recovered Salmonella spp. from SMT were carried out by testing of all the recovered Salmonella spp. in addition to the standard positive and standard negative strains with PCR, using a primer pairs targeting for inv-A gene. All Salmonella spp. were positive for amplification of $284 \mathrm{bp}$ fragments of inv-A gene and all non Salmonella spp. were negative (Figure 1) Lane 1 is the positive control ,Lane 2 showing positive amplification of $284 \mathrm{bp}$ fragments of Salmonella species, while lanes 3-20 showing no amplification. All the examined field samples with SMT as well as the negative control samples were tested by PCR using the same primer pairs after selective enrichment on RV broth. All bacteriologically positive samples (100\%) were positive by PCR and amplification of 284 fragments specific for inv- $A$ gene was observed. The negative control samples were negative for the PCR assay and no amplification could be detected with the four primer pairs.

Table 1. Results of standard microbiological techniques

\begin{tabular}{rrrrr}
\hline Name of samples & Types of samples & Number of samples & \multicolumn{2}{c}{ Standard microbiological techniques } \\
\hline & & & Total positive & $\%$ \\
Alfaalfa & Forage & 14 & 0 & 0 \\
Cauliflower & Vegetable & 9 & 1 & 1.9 \\
White corn & Forage & 14 & 0 & 0 \\
Tomato & Vegetable & 10 & 0 & 0 \\
Egg plant & Vegetable & 5 & 0 & 0 \\
\hline
\end{tabular}

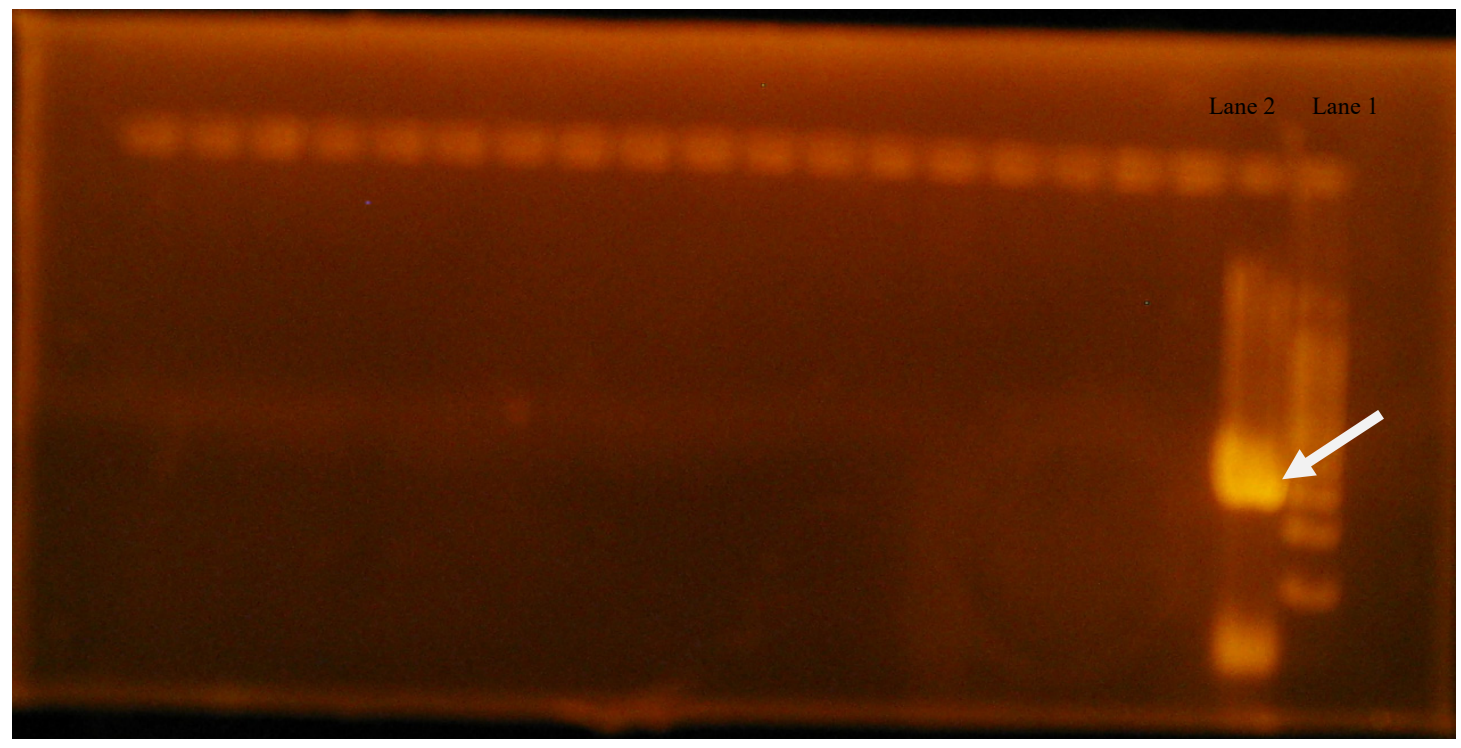

Figure 1. Agarose gel electrophoresis showing amplification of invA genes

\section{Discussion}

Vegetables and forages are one of Salmonella reservoirs that can be transmitted to humans and animals through the food-chain. The detection of Salmonella species by regulatory agencies is still primarily based on standard microbiological techniques which may take up to 7 days to confirm the results (Stoneet al., 1994). The earlier a foodborne outbreak is alleged, the faster the source of the pathogen can be identified, and the sooner the public can recover confidence in the food supply (Stoneet al., 1994). The current study was aimed to investigate the incidence of different Salmonella spp. in fresh vegetables and forages from local source, therefore, 52 samples 
collected from farms were examined by SMT. The results observed in Table 1 revealed a low incidence of Salmonella spp. isolation among both fresh vegetables and forages (1.9\%).

These results indicated the health hazard of fresh vegetables and forages as a inconsequential source of Salmonella foodborne pathogens (Altekruse, Stern, \& Swerdlow, 1999; Humphrey, 2002; Schlundt, 2002). The SMT used in these study reported by ISO 6579 (2002) was characterized by very good analytical parameters which allow the detection of low numbers of potentially stressed cells of various Salmonella spp. through the use of pre-enrichment in BPW followed by selective enrichment in RV broth and finally plated into three different Salmonella selective agars.

Traditional methods of identification of pathogens, which cause disease in humans, are time consuming and laborious although control of the infection depends increasingly on the availability of rapid and precise diagnostic tests for monitoring. Therefore, the present study was aimed to investigate the sensitivity of PCR protocol in conjunction with selective enrichment in Rappaport Vassiliadis broth and compared with standard microbiological techniques. In the present study, the PCR produced positive amplification of $284 \mathrm{bp}$ fragments of invA gene (1.9\%), specific for all members of Salmonella species (Figures 1). This result was parallel to those obtained by Oliveiraet al. (2002) and Malorny et al. (2003), who reported that the primer, which target the invA gene, which is not carried by any other bacterial species (Linet al., 2007), was able to identify all the examined Salmonella species, whereas all non Salmonella species gave negative results. Moreover, PCR has several advantages over the slide agglutination test with polyvalent antisera, because serogrouping is not possible when Salmonella isolates lack O- antigen (rough strain) or lack both O and H antigen (Linet al., 2007).

In conclusion, the PCR assay obviously proved to be a highly specific, sensitive and time saving method for detecting Salmonella. The combination of a routine PCR test in conjunction with SMT could be effective in providing a more accurate profile of the prevalence of Salmonella in fresh vegetable and forage related samples.

\section{Conclusion}

The PCR assay obviously proved to be a highly specific, time saving and sensitive technique for Salmonella detection. The combination of a routine PCR test along with SMT can effectively provide a more correct profile of Salmonella prevalence in fresh vegetable and forage related samples.

\section{References}

Altekruse S.F., Stern, N.J., \& Swerdlow, D.L. (1999). Compylobacter jejuni- An emerging foodborne pathogen. Emerging Infectious Diseases, 1, 28-35.

Altekruse, S.F., Cohen, M.L., \& Swerdlow, D.L. (1997). Emerging foodborne disease. Emerg. Infect. Dis., 3, 285-293.

Bailey, J.S. (1998). Detection of Salmonella cells within 24-26 hrs in poultry samples with the PCR BAX system. J. Food Prot., 61, 792-795.

Bennett, A.R., Greenwood, D., Tennant, C., Banks, J.G., \& Betts, R.P. (1998). Rapid and definitive detection of Salmonella in foods by PCR. Lett. Appl. Microbiol., 26, 437-441.

Bhagwat, A.A., \& Lauer, W. (2004). Food borne outbreaks in raw produce can be prevented. Food quality, 11, 62-63.

Blostein, J. (1991). An outbreak of Salmonella javiana associated with consumption of watermelon. J. Environ. Health, 56, 29-31.

Centers for Disease Control and Prevention. (1979). Salmonella oranienburg gastroenteritis associated with consumption of precut watermelons, Illinois. Morb. Mortal. Wkly Rep., 28, 522-523.

Centers for Disease Control and Prevention. (1993). Multi-state outbreak of Salmonella serotype Montivideo infections. Centers for Disease Control and Prevention, Atlanta, Ga, Publication EPI-AID, 93-97.

Chen, S., Yee, A., Griffiths, M., Larkin, C., Yamashiro, C.T., Behari, R., Paszko-Kolva, C., Rahn, K., \& De Grandis, S.A. (1997). The evaluation of a fluorogenic polymerase chain reaction assay for the detection of Salmonella species in food commodities. Int. J. Food Microbiol., 35, 239-250.

Doran, J.L., Collinson, S.K., Burian, J., Sarlos, G., Todd, E.C.D., Munro, C.K., Kay, C.M., Banser, P.A., Peterkin, P.I., \& Kay, W.W. (1993). DNA-based diagnostic test for Salmonella species targeting agfA, the structural gene for thin aggregative fimbriae. J. Clin. Microbiol., 31, 2263-2273.

Gayler, G.E., MacCready, R.A., Reardon, J.P., \& McKernan, B.F. (1955). An outbreak of salmonellosis traced to watermelon. Public Health Rep., 70, 311-313. 
Gooding, C. M., \& Choudary, P.V. (1999). Comparison of different primers for rapid detection of Salmonella using the polymerase chain reaction. Mol. Cell. Probes, 13, 34-347.

Hashimoto, Y., Itho, Y., Fujinaga, Y., Khan, A.Q., Sultana, F., Miyake, M., Hirose, K., Yamamoto, H., \& Ezaki, T. (1995). Development of nested PCR based on the ViaB sequence to detect Salmonella typhi. J. Clin. Microbiol., 33, 775-777.

Hoorfar, J., Baggesen, D.L., \& Porting, P.H. (1999). A PCR-based strategy for simple and rapid identification of rough presumptive Salmonella isolates. J. Microb. Method, 35, 77-84.

Humphrey, T.J. (2002). Contamination of eggs shell and contents with Salmonella entrica serovar Enteritides. In: Salmonella entrica serovar Enteritides in human and animals. Epidemiology, Pathogenesis, and Control. Lowa State University Press, Ames, IA, 183-192.

Iida, K., Abe, A., Matsui, H., Danbara, H., Wakayama, S., \& Kawahara, K. (1993). Rapid and sensitive method for detection of Salmonella strains using a combination of polymerase chain reaction and reverse dot-blot hybridization. FEMS Microbiol. Lett., 114, 167-172.

Keusch, G.T. (2002). Systemic gastro-intestinal infections: a clinical overview. In M. Sussman (Ed.), Molecular Medical Microbiology. San Diego: Academic Press.

Kimura, B., Kawasaki, S., Fujii, T., Kusunoki, J., Itoh, T., \& Flood, S.J.A. (1999). Evaluation of TaqMan PCR assay for detecting Salmonella in raw meat and shrimp. J. Food Prot., 62, 329-335.

Lin, C.L., Chiu, C.H., Chu, C., Huang, Y.C., Lin, T.Y., \& Ou, J.T. (2007). A multiplex chain reaction method for rapid identification of Citrobacter freundii and Salmonella species, including Salmonella Typhi. J. Microbiol. Immunol. Infect. 40, 222-226.

Mahon, B.E., Pönkä, A., Hall, W., Komatsu, K., Beuchat, L., Dietrich, S., Siitonen, A., Cage, G., Lambert-Fair, M., Hayes, P., Bean, N., Griffin, P., \& Slutsker, L. (1997). An international outbreak of Salmonella infections caused by alfalfa sprouts grown from contaminated seed. J. Infect. Dis., 175, 876-882.

Mahon, J., \& Lax, A. (1993). A quantitative polymerase chain reaction method for the detection in avian faeces of salmonellas carrying the $s p v R$ gene. Epidemiol. Infect., 111, 455-464.

Malorny, B., Hoorfar, J., Hugas, M., Heuvelink, A., Fach, P., EllerbroekBunge, C., Dorn, C., \& Helmuth, R.L. (2003). Interlaboratory diagnostic accuracy of a Salmonella specific PCR-based method. Int. J. Food Microbiol., 89, 241-249.

Moussa, I. M., Gassem, M. A., Al-Doss, A. A., Sadik, M.W.A., \& Abdel Mawgood, A. L. (2010). Using molecular techniques for rapid detection of Salmonella serovars in frozen chicken and chicken products collected from Riyadh, Saudi Arabia. African Journal of Biotechnology, 9(5), 612-619.

O’Mahony, M., Cowden, J., Smyth, B., Lynch, D., Hall, M., Rowe, B., Teare, E.L., Tettmar, R.E., Coles, A.M., Gilbert, R.J., Kingcott, E., \& Bartlett, C.L.R. (1990). An outbreak of Salmonella saint-paul infection associated with bean sprouts. Epidemiol. Infect., 104, 229-235.

Oliveira, S.D., Santos, L.R., Schuch, D.M.T., Silva, A.B., Salle, C.T.P., \& Canal, C.W. (2002). Detection and identification of Salmonellas from poultry by PCR. Vet. Microbiol., 87, 25-35.

Rahn, K., De Grandis, S.A., Clarke, R.C., McEwen, S.A., Galan, J.E., Ginocchio, C., Curtiss III, R., \& Gyles, C.L. (1992). Amplification of an invA gene sequence of Salmonella typhimurium by polymerase chain reaction as a specific method of detection of Salmonella. Mol. Cell. Probes, 6, 271-279.

Rexach, L., Dilasser, F., \& Fach, P. (1994). Polymerase chain reaction for Salmonella virulence-associated plasmid genes detection: a new tool in Salmonella epidemiology. Epidemiol. Infect., 112, 33-43.

Schlundt, J. (2002). New directions in foodborne disease prevention. Int. J. Food Microbiol., 78, 3-17.

Stone, G.G., Oberst, R.D., Hays, M.P., McVey, S., \& Chengappa, M.M. (1994). Detection of Salmonella serovars from clinical samples by enrichment broth cultivation-PCR procedure. J. Clin. Microbiol., 32, 1742-1749.

Wang, H., Blais, B.W., \& Yamazaki, H. (1995). Rapid confirmation of polymyxin-cloth enzyme immunoassay for group D salmonellae including Salmonella enteritidis in eggs by polymerase chain reaction. Food Control, 6, 205-209.

\section{Copyrights}


Copyright for this article is retained by the author(s), with first publication rights granted to the journal.

This is an open-access article distributed under the terms and conditions of the Creative Commons Attribution license (http://creativecommons.org/licenses/by/4.0/). 